\title{
Provincial Government Authorities in the Grant Distribution to the Community in Bali
}

\author{
Agung Herwanto ${ }^{1}$, I Nyoman Putu Budiartha ${ }^{2}$ and I Gusti Bagus Suryawan ${ }^{3}$ \\ \{agung.herwanto@gmail.com, putu.budiartha59@gmail.com and suryawanmeraku@gmail.com\} \\ Universitas Warmadewa, Denpasar, Bali - Indonesia
}

\begin{abstract}
Ratification of Indonesian Law Number 23 of 2014 concerning Regional Government has excluded the concept of 'Community Groups' in the distribution of grants, and consequently indecision in distributing the grants significantly arises. On these grounds, this study examines the Bali provincial government authorities in distributing grants to the community, as well as reviews the legal certainty for granted community. This study was designed in a normative legal research method using statute and conceptual approaches. The results show that Bali provincial government authorities in the grant distribution is stipulated in Article 298 paragraph (4) of Law Number 23 Year 2014; the granted community groups are required to fulfill the requirements as set out in the Minister of Home Affairs Regulation Number 32 of 2011, which has been amanded to Minister of Home Affairs Regulation Number 14 of 2017, and followed up with Bali Governor Regulation Number 2 of 2017.
\end{abstract}

Keywords: Community group; grant distribution; provincial government

\section{Introduction}

A number of previous studies and existing literatures on law and governments have made focus on discussions of the roles and authorities of goverments in providing for community the welfare through granting from the state. It is that public activities to survive for their llives are necessarily supported by the government [1,2]. In the context of Indonesia, the distribution of grants to the community by the Regional Government is based on Minister of Home Affairs Regulation No. 32/2011 concerning Guidelines for Awarding Grants and Social Assistance originated from regional income and expenditure budgets. The governing rules have been amanded to the Minister of Home Affairs Government Regulation No. 39/2012, which then followed up with Bali Governor Regulation Number 67 of 2012 concerning Guidelines for Awarding Grants and Social Assistance sourced from the Regional Revenue and Expenditure Budget. This is as also happened to Bali, one of the provinces in Indonesia. Provincial and regional government in their respective autonomous field of authorities should rule out the community life based on their interests, which are of course closely related to their condition of environment [3]. Granting for society is one of the duties of the state to provide the society with primary service in order to create a harmony life for them [2]. Thus, the government is said to be the holder of control over society interests.

So what are the objectives of granting? Indonesian Minister of Home Affairs Regulation Number 32 Year 2011, in Article 5, states that grants are awarded to the government; other regional governments; regional company; community; and/or community organizations. The community in question is a group of people who have certain activities in the fields of 
economy, education, health, religion, arts, customs, and non-professional sports [4]. Furthermore, Bali Governor Regulation Number 67 of 2012, in Article 5 paragraph (4), states: "Community/community groups/indigenous peoples are groups of people who have certain activities in the fields of economy, education, health, religion, arts, customs and nonprofessional sports. The Regional Government of Bali Province has the authority to award grants to the community as a community group, and/or indigenous people who have the elements: consisting of a group of people, having certain activities in the fields of economy, education, health, religion, arts, customs and non-sports professional. This is a form of government authority realization for the welfare of society. Unfortunately, regulations regarding this matter no longer apply separately to the community or community groups after Law No. 23 of 2014 concerning Regional Government was issued. Hence, these community groups or indigenous peoples are no longer specifically recorded as recipients of grants from the provincial government. Article 298 paragraph (5) of the Law on Regional Government stipulates that grant expenditure can be given to: a. Central government; b. Other Regional Governments; c. state-owned enterprise or BUMD; and/or d. community organizations, institutions and organizations incorporated in Indonesia.

The question is that from the provisions of the new law, can community groups or indigenous peoples be classified as organizations/institutions incorporated in Indonesia? Since the Law on Regional Government has been implemented, doubts and confusion in the implementation of the distribution of grants in areas including the provincial government of Bali, emerged. The law sounds very general and does not explain specifically. After that, the Minister of Home Affairs Regulation Number 14 of 2016 concerning the second amendment to the Minister of Home Affairs Regulation Number 32 Year 2011 was issued. In Article 6 paragraph (5) letter c, it is stipulated that the agency/institution is "non-profit, voluntary, social-community in the form of community groups/customary law community units insofar as they are alive and in accordance with community development, and their existence is recognized by the central government and/or regional government through ratification or stipulation from the head of the vertical agency or the head of the relevant regional work unit in accordance with his authority.

From the formulation of the above provisions, the agency/institution is defined as a nonprofit, voluntary and social community group. Thus the community groups as grant recipients are accommodated in the Minister of Home Affairs Regulation Number 14 of 2016. Furthermore, on this basis, the provincial government of Bali sets Bali Governor Regulation Number 2 of 2017 concerning Guidelines for Granting and Social Assistance, which are used as the basis of the authority of the Provincial Government to grant Grants to Non-profit, voluntary and social groups. Is the expansion of the concept of agency/institution into a nonprofit, voluntary and social community group, not violating the provisions in Article 289 paragraph (5) letter d of Law Number 23 Year 2014, and how is legal certainty for community groups as receiving grants? This study examines the authority of the provincial government in distributing grants to community groups. In addition, we reveal forms of legal certainty for community groups that can receive grants from provincial governments.

The study is a normative law research, which is intended to bring closer the problem under study with conceptual approach and statute approach with its regulation. For analysis purposes, primary, secondary, and tertiary legal materials were required. The techniques used in collecting legal materials were library research and cyber media. Data were analyzed descriptively interpretation, i.e. interpretation in the articles of law by linking the law articles in other laws and regulations, those which are closely related to Indonesian law of grant distribution, and expanding the meaning of the words contained in the legislation. 


\section{Results and Discussion}

2.1 Bali Provincial Government Authorities in Grant Distribution to the Community.

Regional government is a government agency that carries out government affairs and regional councils according to the principle of autonomy and co-administration with the broadest principle of autonomy in the system and principles of the Unitary State of the Republic of Indonesia as mandated in the 1945 Constitution of the Republic of Indonesia. Autonomy is the right, authority and obligation of the region to regulate and manage their own household in accordance with the applicable laws and regulations [5].

The nature of authority has actually become a general knowledge base for all elements of society in a country. In line with Hadjon's idea, the way to obtain authority consists of two main ways, namely: a) attribution; b) delegation; and sometimes the mandate [6]. An attribution is the authority to make decisions (besluit) that are directly sourced from the law in the material sense [7]. This attribution is also said to be a normal way to obtain government authority. From this standpoint, it appears that the authority obtained through attribution by government is the original authority, because it is obtained directly from the legislation. In other words, with the term attribution, new authority which was not previously owned by the relevant government organs became formed and owned. Despite complaints in certain regions about ethnic favouritism there is no evidence to suggest that narrowly sectional or party political considerations have influenced the allocation of resources - either between provinces or within them, except in the understandable priority accorded to certain aspects of 'delivery' to poor communities in preference to maintaining basic infrastructure [8]. The delegation is defined as the surrender of authority to make the expenses by government officials to other parties [9]. In other words, there is a transfer of responsibility from the one who delegates to the one who receives the delegation (delegetaris). Whereas the notion of mandate requires that responsibility does not move to the mandate, but remains in the hands of the creditor.

The authority of the regional government in the distribution of grants is regulated in the Minister of Home Affairs Regulation Number 32 of 2011, as amended to become Minister of Home Affairs Regulation Number 14 of 2016, in Article 4 paragraph (1), which states, "Local governments can grant grants according to their ability regional finance ". As a follow up to the granting of grants by local governments, based on Article 42 paragraph (1) of the Minister of Home Affairs Regulation, it is determined that the procedures for budgeting, implementation and administration, accountability and reporting and monitoring and evaluation of grants and social assistance are further regulated by regional head regulations and paragraph (3) stipulates that the regional government can budget grants and social assistance if it has established regulations for the regional head. On the basis of the aforementioned provisions, the provincial government of Bali establishes Bali Governor Regulation Number 2 of 2017 concerning Guidelines for Awarding Grants and Social Assistance.

The authority to grant grants by regional government regulated in the Minister of Home Affairs Regulation Number 14 of 2016 as the implementation of Law Number 23 of 2014 concerning Regional Government, Article 298 paragraph (4) in principle determines that the expenditure of grants is budgeted in the APBD (Regional Budget) according to the ability regional finance after prioritizing Mandatory Government Affairs and Preferred Government Affairs. Thus, the granting of grants by local governments is carried out with the aim of supporting regional government affairs [10]. Obtaining authority obtained from legislation is formal legality, which legitimizes government actions. This is in accordance with the principle of the rule of law which places the law as a source of authority. 
Government actions, also called bestuurs handeling, are actions carried out by equipment in high and low levels of government/authorities spontaneously and independently to preserve the interests of the state and the people. Government actions or State Administration can be in the form of concrete actions from the government (Feitelijk Handelingen) or legal actions from the government (rechtshandelingen), the government's real action is zijn handelingen waarmee niet wordt beoogd juridische gevolgen in het leven te reopen [11].

Government actions based on law are divided into public legal actions and private legal actions. Actions based on public law are then subdivided into unilateral actions (eenzijdig) and various parties (eerzijdige) [12]. Unilateral legal actions are further divided into interne beschikking, decisions made to carry out relations in the environment of the state apparatus that makes them, and externals beschikking, decisions made to carry out relations between two or more state instruments. The State Administrative Decision is an example of one-sided legal action which is an external measure [13]. Distributing regional grants is a legal action from the regional government to support the implementation of regional government affairs.

According to Article 1 number 14 of the Minister of Home Affairs Regulation No. 32 of 2011, the distribution of regional grants is the distribution of money/goods or services from the regional government to the government or other regional governments, regional companies, communities and community organizations whose designation has been specified mandatory, non-binding, and not continuous, which aims to support the implementation of regional government affairs. Thus, the object of granting includes money/goods or services with the aim of supporting the implementation of regional government affairs which are the authority of autonomous regions in the provision of public services. Giving the grants is intended to support the achievement of program objectives and activities of regional government by taking into account the principles of justice, compliance, rationality and benefits for the community [14]. Grants given to grantees must indeed support the achievement of the goals and activities of the regional government, which rests on the principle of justice, namely the balance of the distribution of authority and funding objectively; the principle of compliance is an action or an attitude that is done fairly and proportionally; the principle of rationality, namely the decision on the grant of grants really reaches the target and can be accounted for; and the principle of benefit for the community, namely regional finance is prioritized for meeting community needs [13].

The Minister of Home Affairs Regulation 32 of 2011, as amended into Minister of Home Affairs Regulation Number 14 of 2016, stipulates that the mechanism for granting grants is preceded by requests or proposals from applicants either from the central government, other regional governments, State-Owned Enterprises Regional-Owned Enterprises, agencies and institutions, and community organizations can submit proposals for grants in writing and addressed to regional heads, and then the regional heads appoint related Regional Work Unit (SKPD) (through disposition and/or appointment through regional head decisions) to evaluate the proposal. To evaluate the problem, the relevant SKPD formed an evaluation team. The results of the team's evaluation were submitted in the form of recommendations to regional heads through the Regional Government Budget Team (TAPD). Acceptable or not, the proposal made is very much determined by the results of the evaluation team through its recommendations. The evaluation team, of course, will evaluate the conditions for granting grants as well as the terms and criteria of grantees. TAPD gives consideration to recommendations in accordance with regional financial priorities and capabilities. In principle TAPD is only limited to giving consideration to the ability of regional finances, because administrative feasibility and whether or not the proposal of the applicant is accepted is also 
determined by the results of the evaluation through the recommendations of the relevant SKPD.

The recommendation of the SKPD head who evaluates the administrative feasibility of the applicant relating to the validity of grant conditions, and the terms and criteria of recipients and TAPD considerations on regional financial capacity, are the basis for the inclusion of grant budget allocations in the draft Budget General Budget (KUA) and Priority Budget Ceiling Priority (PPAS), both the budget for grants in the form of money, goods and/or services. Therefore, budgeting for grants must be included earlier in the KUA and PPAS. Thus, the inclusion of a grant budget may not occur suddenly. In other words, the inclusion of a grant budget was made at the time of drafting the Regional Revenue and Expenditure Budget (RAPBD), moreover the grant budget would be proposed and/or included in the RAPBD discussion between TAPD and the Regional People's Representative Council (DPRD) budget. After the grant budget is included in the KUA and PPA, the inclusion of a grant in the form of money is included in the Budget Work Plan - Regional Financial Management Officer (RKAPPKD) and grants in the form of goods or services are included in the Budget Work Plan (RKA-SKPD) according proposed field. Furthermore, RKA-PPKD and RKA-SKPD are the basis for budgeting grants in the Regional Budget and Expenditure Plan (RAPBD). In Article 42 of the Minister of Home Affairs Regulation No. 32 of 2011, which was changed to Minister of Home Affairs Regulation No. 14 of 2016, it is determined that there is a need to establish regional head regulations, which were an absolute requirement for regional governments to budget grants. On this basis, the provincial government of Bali stipulates Bali Governor Regulation Number 2 of 2017.

The mechanism for budgeting Bali provincial government grants is regulated in Article 8 of Bali Governor Regulation Number 2 of 2017, i.e.:

a. The central government, other regional governments, State-Owned Enterprises or Regional-Owned Enterprises, agencies and institutions, and community organizations can submit proposals for grants in writing to the Governor through the General Bureau of Regional Secretariat of Bali Province.

b. The General Bureau of the Regional Secretariat of the Province of Bali distributes proposals to the Regional Apparatus/Related Work Units according to their fields of affairs.

c. A written proposal is signed and affixed with a stamp by: a) Chairperson/Chairperson/Head or other designation of Agency/Work Unit for the government; b) Regent/Mayor for other regional governments; c) Main Director or other designation for BUMN/BUMD; d) Chairperson and Secretary or other designations for social institutions, institutions and organizations.

d. Written proposals from prospective grantees at least contain: a) background; b) purpose and objectives; c) details of the budget; and d) execution time;

e. Written proposals from prospective recipients are equipped with a Statement Letter stamped Rp. 6000, - (six thousand rupiahs) which states that it is true that the person concerned did not receive the grant within the previous 1 (one) year from the Bali provincial government and/or Regency/City.

f. The proposal for the longest submission submitted in March of the year is favorable for the Regional Budget of the following year, while the change in APBD is the longest delivered in June in the budget year it is pleased.

g. Proposal for APBD Amendment grants only for activities that can be implemented until the end of the fiscal year is acceptable. 
Furthermore, in Article 9 and Article 10 of Bali Governor Regulation Number 2 of 2017, the Head of Regional Equipment/Related Work Units based on the field of government affairs submits evaluation results in the form of recommendations to the Governor through TAPD, in this case the Regional Development Planning Agency (Bappeda) and Research and Development (Litbang) of Bali Province. TAPD gives consideration to recommendations in accordance with regional financial priorities and capabilities. The recommendations of the Head of the District/Work Unit and TAPD considerations form the basis for inclusion of the budget allocation of the grant in the KUA and PPAS designs and the draft KUA/PPAS Amendment. Inclusion of budget allocations includes the budget for grants in the form of money/goods, or services.

\subsection{Legal Certainty for the Granted Community Group to Reward from Bali Provincial Government}

Legal certainty is a value that in principle provides legal protection for every citizen from arbitrary actions from the state and other parties besides the State, so that the law gives responsibility to the state and every other person or party to carry it out. To understand the value of legal certainty, it must be associated with a positive legal instrument and the role of the state to actualize the positive law that the state has the responsibility of carrying out and enforcing it. Therefore, legal certainty cannot be separated from the rule of law [15].

Radbruch put forward four basic things related to the meaning of legal certainty, namely: first, that the law is positive, meaning that the law is a law; second, that the law is based on facts, in the sense that it is based on reality; third, that facts must be formulated in a clear manner so as to avoid mistakes in meaning, besides being easy to implement; fourth, positive law cannot be easily changed. Legal certainty is a guarantee that the law is carried out, parties who have the right according to the law can obtain their rights, even though legal certainty is closely related to justice, but the law is not identical with justice [16, 17] . Law is general, binding everyone, generalizing, while justice is subjective, individualistic and not generalized [18]. Legal certainty is the implementation of the law in accordance with the doctrine so that the community can ensure that the law is implemented.

Condition of the concepts or theories of legal certainty described above and in the previous chapters indicates the elements of legal certainty as revealed by Scheltema, cited by Budiarta, namely: (1) Principle of legality, (2) The existence of laws that regulate authorized actions in such a way that citizens can know what to expect, (3) The law may not be retroactive, (4) Control that is free from the influence of other powers.

From these elements, it can be seen that the nature of legal certainty is 1) definite regarding its legal rules governing government issues in the abstract; 2) definitely regarding the legal position of the subject and its legal object in the implementation of administrative law; and 3) prevent the possibility of arising from arbitrary acts (eigenrechting) from any party, as well as actions from the state [15].

Observing the elements and meaning of legal certainty, it can be said that the nature of legal certainty is the existence and consistency of the subject and object of law in legal regulations, the implementation of legal regulations, and in enforcing the legal regulations to provide legal protection for loyal citizens arbitrary state and other parties besides the state. Elements of the meaning or nature of legal certainty cannot be separated from legal certainty as a legal principle. One of the principles of universal law is the principle of legal certainty. The principle of legal certainty in Indonesia has become the principle of national law, so that legal certainty must be a reference in every formation and material content of legal 
regulations, as determined in Article 6 paragraph (1) letter i of Law Number 12 Year 2011 along with explanations [15].

With regard to the enactment of Law Number 23 of 2014, for orderly administration and the creation of harmonization, stability, effectiveness and guaranteeing community participation to strengthen support for the implementation of regional government, the Minister of Home Affairs stipulates regulations on the second amendment to Minister of Home Affairs Regulation Number 32 Year 2011. Thus, the Minister of Home Affairs Regulation Number 14 of 2016 in Article 5 is stipulated, which determines: grants can be given to: a) Central Government; b) Other regional governments; c) State-Owned Enterprises or Regional-Owned Enterprises; and/or d) Community agencies, institutions and organizations incorporated in Indonesia.

Furthermore, in Article 6 paragraph (5) letter c, the Minister of Home Affairs Regulation Number 14 of 2016, related to the agency, is explained that the institution is a non-profit, voluntary, social community in the form of community groups/customary law community units as long as they are in accordance with the development of the community, and its existence is recognized by the central government and/or regional government through ratification or stipulation from the head of the vertical agency or the head of the relevant regional work unit in accordance with its authority.

The nature of community groups is regulated in Article 6 paragraph (4) of the Minister of Home Affairs Regulation Number 32 Year 2011 having relations with the provisions of Article 6 paragraph (5) letter c, Minister of Home Affairs Regulation Number 14 of 2016, which stipulates: non-profit agencies voluntary, societal nature in the form of community groups/customary law community units insofar as they are alive and in accordance with community development, and their existence is recognized by the central government and/or regional government through endorsement or stipulation from the head of a vertical agency related to their authority. Community groups as recipients of grants have been accommodated, and clarified again with non-profit, voluntary and social phrases, and even extended to customary law community units as long as they are alive and in accordance with community development, and their existence is recognized by the central government and/or government area.

Community units that are still alive and in accordance with the development of the community and their existence recognized by the central government or regional government have also been accommodated as recipients of the grant, meaning as the subject of the rights that the local government can grant. In fact, the ownership of communal rights to land has also been recognized by the enactment of the Minister of Agrarian and Spatial Planning/Head of the National Land Agency by its Decree Number 276/KEP-19.2/X/2017 dated 23 October 2017 concerning the Appointment of Pakraman Village in Bali Province as Right Subject Joint (communal) ownership of land. Indicator of Pakraman Village in Bali Province as the subject of communal ownership of land with the following conditions: a. there are members of the community who are still in the form of community; $b$. there are institutions and instruments of customary mastery; c. there is a land of communal ownership rights with clear boundaries; and D. there are institutions and legal instruments that are still adhered to.

Related to the regulation regarding the implementation of grants as determined in the Minister of Home Affairs Regulation Number 32 Year 2011, which has been amended to become Minister of Home Affairs Regulation Number 14 of 2016, as a follow up, the provincial government of Bali adapts to existing legal conditions and needs, so that the Bali Governor's Regulation Number 2 of 2017 is stipulated and promulgated. In relation to community groups, Bali Governor's Regulation No. 2 of 2017 follows the provisions 
contained in the Minister of Home Affairs Regulation No. 14 of 2016. Likewise with the explanation that states that agencies and institutions: are non-profit, voluntary, social in nature in the form of community groups/customary law community units as long as they are alive and in accordance with the development of the community, and their existence is recognized by the central government and/or regional government through ratification or stipulation from the head of the vertical agency or the leadership of the relevant regional apparatus in accordance with their authority.

Criteria and requirements for community groups as recipients of grants are regulated in Article 7 paragraph (1) of Bali Governor Regulation Number 2 of 2017, which in principle determines: a community group must have clear management; its management is proven by the management structure, both in the form of decisions and not in the form of decisions. Located in the administrative area of the provincial government of Bali, community groups have been established for 2 years; they must have a domicile certificate at the place of activity of the community group and have proof of ratification from the Vertical Agency or the Regional Apparatus concerned to prove the validity of the community group.

Grant recipients are required to submit a report about the responsibility for the grant received and its use in accordance with its activities, to the local government as the grantor. Setting the accountability report for the use of grants for grantees based on Bali Governor Regulation Number 2 of 2017, is regulated in detail and clearly: starting from the submission of accountability reports to the governor through the PPKD (Financial and Asset Management Agency) whose copies are submitted to the Regional/Work Unit the accountability report for the use of the grant includes the report on the use of the grant, in the form of details of the use of the grant expenditure signed by the treasurer and the leader of the community group; statement of responsibility if necessary, accompanied by a copy of the complete and legal proof of expenditure for the recipient of the grant.

Furthermore, the accountability report on the financial use of the recipient of the grant is submitted first to the governor, no later than the 10th of the following fiscal year. If specified by law and regulation, that is an exception. Meanwhile, the recipient's accountability report in the form of goods/services is delivered to the Governor through the Head of Regional Equipment/Work Unit. The most important thing is that legal responsibility for the use of grants both formally and materially is in the hands of the recipient of the Grant.

Meanwhile, the provincial government accountability report of Bali for grants is explained in Article 22 of Bali Governor Regulation Number 2 of 2017, which includes (a) proposals from potential grantees to the Governor through SKPD/related work units, (b) governor's decision regarding the determination of the list of recipients of hiba, (c) NPHD, (d) Facts of Integrity of the recipient of the grant stating that the grant received will be used in accordance with NPHD; and (e) proof of money transfers for the provision of grants in the form of money or evidence of handover of goods/services for grants in the form of goods/services.

\section{Conclusion}

The authority of the provincial government of Bali in the distribution of grants is the authority of attribution originating from legislation. This is in accordance with the principle of the rule of law which places the law as a source of authority. Hence, the authority of attribution gives legitimacy to the actions of provincial governments in the distribution of 
grants to community groups. Legal certainty in the community groups as recipients of grants from the provincial government, namely each community group must meet the criteria and requirements as stipulated in legislation (Bali Governor Regulation), as its legality. This includes the processes and mechanisms of implementation; starting from proposals/grant proposals, evaluations, to recommendations from relevant Regional Devices.

The provincial government of Bali is trying to propose a change to Law 23 of 2014, specifically article 298 paragraph (5) letter d, so that in its explanation information is given about the concept of the body, the institution continues to pay attention to community groups/legal entities that live and develop and exist recognized. Courage from the relevant regional apparatus in conducting evaluations and recommendations of grantees is needed if indeed the results of the evaluation of the recipient of the grant do not meet the criteria and requirements as recipients of the grant, so that it is returned and does not need to be recommended. This is done as a preventive measure so as not to cause legal problems.

\section{References}

[1] Veeneman, W and Mulley, C.: Multi-level governance in public transport: Governmental layering and its influence on public transport service solutions, Res. Transp. Econ. pp. 0-1 (2018)

[2] Maimunawaroh, S and Antikowati, A.: Kewenangan Pemerintah Daerah dalam Pemenuhan Bantuan Hukum bagi Masyarakat Miskin di Kabupaten Jember, Lentera Huk, vol. 5 (2). p. 259 (2018)

[3] Anjum, Z, H.: New local government system: A step towards community empowerment?, Pak. Dev. Rev. vol. 40 (4). pp. 845-867 (2001)

[4] Khemani, S.: Fiscal Federalism and Service Delivery in Nigeria: The Role of States and Local Governments, Prep. Niger. PER Steer. Committee, pp. 1-16 (2001)

[5] Soehino.: Hukum Tata Negara: Perkembangan Otonomi Daerah. Yogyakarta: BPFE (1991)

[6] Hadjon, P, M.: Pengertian-Pengertian Dasar Tentang Tindak Pemerintahan (Bestuurhandeling). Surabaya (1985)

[7] Harbour, J and Wilson, J.: Political management and local government: The views of local authority chief executives, Public Money Manag. vol. 23 (1). pp. 51-58 (2003)

[8] Lodge, T.: Provincial government and state authority in South Africa, J. South. Afr. Stud. vol. 31 (4). pp. 737-753 (2005)

[9] Umashev, C and Willett, R.: Challenges to implementing strategic performance measurement systems in multi-objective organizations: The case of a large local government authority, Abacus, vol. 44 (4). pp. 377-398 (2008)

[10] Public, I and Journal, M.: Local Authority E-Government Partnerships In England: A Case Study, vol. 26. pp. 42-64 (2010)

[11] Van Ballegooij, G, A, C, M and Al, E.: Bestuursrecht in het Awb-Tijperk, zesde, geheel herziene druk, Kluwer. Nederland: Oegstgeet (2008)

[12] Harjon, P, M.: Tentang Wewenang Pemerintahan (bestuurbevoegheid dalam "Pro Justitia" Jakarta: Sinar Grafika (1998)

[13] Utrecht, E.: Hukum Administrasi Negara Indonesia. Bandung: FHMP Universitas Negeri Padjajaran (1960)

[14] King, D, N and Ma, Y.: Central Government Control over Local Authority Expenditure: The Overseas Experience, Public Money Manag. vol. 19 (3) pp. 23-28 (1999)

[15] Budiarta, I, N, P.: Hukum Outsoourcing (Konsep Alih Daya, Bentuk Perlindungan, dan Kepastian Hukum). Malang: Setara Pres (2015)

[16] Neuhaus, P, H.: Legal certainty versus equity in the conflict of laws, Law Contemp. Probl. vol. 56 (1952). pp. 795-807 (1963)

[17] Portuese, A, Gough, O and Tanega, J.: The principle of legal certainty as a principle of economic efficiency, Eur. J. Law Econ. vol. 44 (1) pp. 131-156 (2017)

[18] Duperron, R, A.: Interpretation Acts-Impediments to Legal Certainty and Access to the Law, Statut. Law Rev. vol. 26 (1) pp. 64-68 (2005) 
